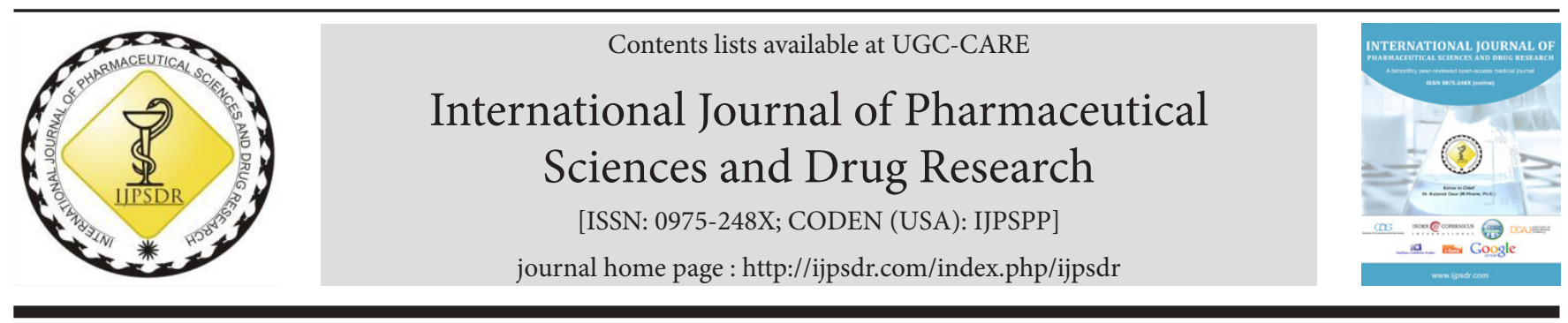

Research Article

\title{
Docking against Lung Cancer Protein and Drug-likeliness of Bioactive Compounds from Phymatosorus scolopendria (Burm. f.)
} Pic. Serm.

\author{
Sujatha Srinivasan, Catharin S. Sivaraman*, Ramya R. Issac, Gayathiri Mahalingam, Gnana D. R. Roke \\ PG and Research Department of Botany, Holy Cross College (Autonomous), Affiliated to Bharathidasan University, Tiruchirappalli, Tamil Nadu, India
}

\author{
ART I CLE INFO \\ Article history: \\ Received: 06 March, 2020 \\ Revised: 11 August, 2020 \\ Accepted: 25 August, 2020 \\ Published: 30 September, 2020 \\ Keywords: \\ Docking, Gas chromatography- \\ mass spectroscopy (GC-MS), \\ Lung cancer protein, \\ Phymatosorus scolopendria \\ (Burm. f.) Pic. Serm. \\ DOI: \\ 10.25004/IJPSDR.2020.120502
}

\begin{abstract}
A B S T R A C T
Phymatosorus scolopendria (Burm. f.) Pic. Serm. is a medicinally important fern that is used traditionally by various people all over the world. This research focuses on the docking against lung cancer protein (2ITO) with bioactive compounds of P. scolopendria (Burm. f.) Pic. Serm., which is obtained by using gas chromatography-mass spectroscopy (GC-MS). The same compounds were analyzed using Lipinski's rule of five for its pharmacological prediction. The bioactive compounds were further referred for absorption, distribution, metabolism, excretion and toxicity (ADMET) property to find its pharmacokinetic potency and prediction towards its potential as a future drug. Among the four compounds docked with the lung cancer protein (2ITO), 4-nitrophenyl laurate shows a high docking score, followed by hexadecanoic acid, 4-nitrophenyl ester, and myristic acid vinyl ester. Out of four compounds studied, three compounds satisfied the drug-likeliness based on Lipinski's rule of five. The present work suggests the bioactive compounds of P. scolopendria (Burm. f.) Pic. Serm. for further in vitro and in vivo studies for its anti-cancer benefits, especially lung cancer.
\end{abstract}

\section{INTRODUCTION}

Phymatosorus scolopendria (Burm. f.) Pic. Serm. belongs to the family Polypodiaceae, which is commonly known as musk fern or wart fern, and it is an epiphytic fern. Traditionally, in New Guinea, the plant is heated over a fire, and the smoke given off is inhaled to relieve catarrh. The roots with parts of other plants may be used to relieve nasal congestion. ${ }^{[1]}$ In Madagascar, the plant is used for anti-inflammatory, antitussive, and asthma treatment. ${ }^{[2,3]}$

In Polynesia, the plant is traditionally used to clean the bath for newborns, dysmenorrhea, gonorrhoea, leukorrhea, sore throat, asthma, purgative, wound healing, antiemetic, sprain, and healing of fractured bones. ${ }^{[1,4,5]}$ The young fronds are used to treat chronic diarrhea and used as a repellent for bed bugs. ${ }^{[6]}$
Phy tochemically, the plant contains a phenolic compound, especially coumar, which is having bronchodilator activity. ${ }^{[3,7]}$ It is also reported that the plant has beneficial phytochemicals for the treatment of asthma, cough, and inflammatory disease. ${ }^{[2,8]}$ Docking is a procedure to find out the molecular interaction between the phytocompounds obtained from plant extract analyzed through spectroscopic analysis. Based on the earlier phytochemical analysis, the GC-MS was attempted to find out the chemical compounds in the present experimental plants. The molecular interaction patterns between the receptor and the ligand molecules were studied using in silico molecular docking analysis. It is followed by complex data analysis through computational algorithms (i.e., docking algorithms) to predict the complex

\footnotetext{
${ }^{*}$ Corresponding Author: Dr. Catharin Sara Sivaraman

Address: Assistant Professor, PG and Research Department of Botany, Holy Cross College (Autonomous) Tiruchirappalli-620002, Tamil Nadu, India Email $\bowtie$ : sara.kameelasivaraman.catharin@gmail.com

Relevant conflicts of interest/financial disclosures: The authors declare that the research was conducted in the absence of any commercial or financial relationships that could be construed as a potential conflict of interest.

Copyright (c) 2020 Sujatha Srinivasan et al. This is an open access article distributed under the terms of the Creative Commons AttributionNonCommercial-ShareAlike 4.0 International License which allows others to remix, tweak, and build upon the work non-commercially, as long as the author is credited and the new creations are licensed under the identical terms.
} 
structure. Concretely based on references and analysis, no docking studies have been carried out in phytocompounds traced in P. scolopendria so far, especially related to lung cancer, have not been reported. Thus, the present work was planned to perform in silico work on the experimental plant $P$. scolopendria.

\section{Materials AND METhods}

\section{Preparation of Plant Extract}

The plant materials were washed, shade dried and then powdered with the help of a blender. The powder was kept in tight air bottles. Five grams of the powder was extracted through the cold percolation method with $50 \mathrm{~mL}$ of methanol. The extracts were filtered by using Whatman No. 1 filter paper, and the solvents were evaporated to make the crude extract.

\section{GC-MS Analysis}

The crude methanol extracts were subjected to GC-MS analysis for its phytoconstituents. The GC-MS analysis of methanol extract was investigated by Perkin Elmer GC-MS (Model Perkin Elmer Clarus 600, USA) equipped with a VF-5 MS fused silica capillary column $(30 \mathrm{~m} \times 0.25 \mathrm{~mm}$ i.d., film thickness $0.25 \mu \mathrm{m}$ ). Pure helium gas was used as a carrier gas at a constant flow rate of $1 \mathrm{~mL} / \mathrm{minute}$. Mass transfer line and injector temperatures were set at $250^{\circ} \mathrm{C}$. The oven temperature was programmed at $60^{\circ} \mathrm{C}$ for 2 minutes, then increased to $300^{\circ} \mathrm{C}$ for 6 minutes at the rate of $10^{\circ} \mathrm{C} /$ minute. The samples were injected in split mode as 10:1 structural determination by comparing mass spectral patterns to the National Institute of Standards and Technology (NIST) library. The GC-MS studies were carried out at IITM SAIF and sophisticated instrumentation facility (SIF), VIT University, Vellore.

\section{In silico Docking Analysis}

\section{Preparation of Ligands (Small Chemical Molecules)}

The phy tocompounds obtained from GC-MS were developed as a 2D structure and generated into a 3D molecule for the compounds: 1) dodecanoic acid, 1,2,3-propanetriyl ester,
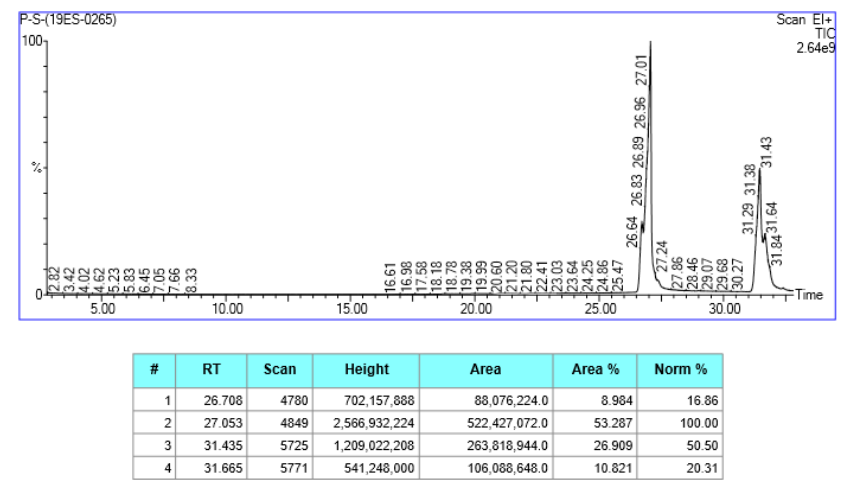

Fig. 1: GC-MS chromatogram obtained from methanolic extract of P. scolopendria (Burm. f.) Pic. Serm.
2) myristic acid vinyl ester, 3) 4-nitrophenyl laurate, and 4) hexadecanoic acid, 4-nitrophenyl ester, using ACD/ ChemSketch software.

Drug-Likeliness Properties according to Lipinski's Rule of Five The SWISS ADME, a free web tool, was used to generate these two compounds' physicochemical, medicinal, and drug-likeness properties. Lipinski's rule, ${ }^{[9]}$ also called the rule of five (RO5), evaluates the drug-likeness or determines if a chemical compound with a certain pharmacological or biological activity has properties that may be active per oral.

\section{Preparation of Receptors (Targets Protein)}

The X-ray crystallographic structure of receptor (2ITOlung cancer protein) was retrieved from Protein Data Bank (PDB) data archives and opened in the software window, then water molecules, heteroatom, and unwanted amino acid chains were removed, missing hydrogen atoms were added, corrections were made for unfilled valence atoms using alternate conformations from 3D downloaded structures of the receptor. Following the above steps of preparation, the protein was subjected to energy minimization using the CHARMm force field.

\section{Active Site Prediction}

The binding pockets or active sites in the receptor were explored using grid/sphere generation based on the cavity detection algorithm combined with the Monte Carlo conformational search for evaluating candidate poses and protein-ligand interaction energies.

\section{Docking Analysis}

The receptor and ligand interaction and its analysis were done with the LibDock module in the Discovery Studio 2.1 version software. The hits were displayed on the output page with total poses of interaction, LibDock score, absolute energy values, hydrogen bond interactions, bond length, and interacting amino acid residues/atoms.

\section{RESUlt AND Discussion}

\section{GC-MS Analysis}

The GC-MS results showed the presence of four bioactive compounds in whole plant methanolic extract of P. scolopendria. The identification of the compounds was confirmed based on the peak area, retention time (RT), molecular formula, molecular weight, and peak area in percentage is presented in Table 1 and Fig. 1. The following are the compounds obtained from GC-MS analysis, viz., 1) dodecanoic acid, 1,2,3-propanetriyl ester, 2) myristic acid vinyl ester, 3) 4-nitrophenyl laurate, and 4) hexadecanoic acid, 4-nitrophenyl ester.

The compound identified in our experimental plant was also identified in Allium sativum through GC-MS; nearly 35 compounds were identified, and among those 
Docking against Lung Cancer Protein and Drug-likeliness of Bioactive Compounds from P. scolopendria

Table 1: Components detected in methanolic extract of P. scolopendria (Burm. f.) Pic. Serm.

\begin{tabular}{|c|c|c|c|c|c|c|c|}
\hline S. No. & Compounds & $R T$ & $\begin{array}{l}\text { Molecular } \\
\text { formula }\end{array}$ & $\begin{array}{l}\text { Nature of } \\
\text { compound }\end{array}$ & $\begin{array}{l}\text { Molecular } \\
\text { weight }\end{array}$ & $\begin{array}{l}\text { Peak } \\
\text { area (\%) }\end{array}$ & Activity \\
\hline 1. & $\begin{array}{l}\text { Dodecanoic acid, } \\
\text { 1,2,3-propanetriyl ester }\end{array}$ & 26.708 & $\mathrm{C}_{39} \mathrm{H}_{74} \mathrm{O}_{6}$ & Fatty acid ester & 638 & 8.984 & $\begin{array}{l}\text { Antioxidant, antibacterial, antiviral, } \\
\text { candidicide, hypocholesterolemic, } \\
\text { antiarthritic, hepatoprotective, } \\
\text { mosquito repellent, cosmetics }\end{array}$ \\
\hline 2. & Myristic acid vinyl ester & 27.053 & $\mathrm{C}_{16} \mathrm{H}_{30} \mathrm{O}_{2}$ & Fatty acid ester & 254 & 53.287 & Antimicrobial, anti-cancer, cosmetics \\
\hline 3. & 4-nitrophenyl laurate & 31.435 & $\mathrm{C}_{18} \mathrm{H}_{27} \mathrm{O}_{4} \mathrm{~N}$ & Fatty acid ester & 321 & 26.909 & Antibacterial \\
\hline 4. & $\begin{array}{l}\text { Hexadecanoic acid, } \\
\text { 4-nitrophenyl ester }\end{array}$ & 31.665 & $\mathrm{C}_{22} \mathrm{H}_{35} \mathrm{O}_{4} \mathrm{~N}$ & Ester & 377 & 10.821 & Cosmetics \\
\hline
\end{tabular}

Table 2: Drug-likeliness analysis using lipinski's rule

\begin{tabular}{|c|c|c|c|c|c|c|}
\hline S. No. & Ligand name & $\begin{array}{l}\text { Molecular weight } \\
<500(\mathrm{~g} / \mathrm{mol})\end{array}$ & $\begin{array}{l}\text { Hydrogen bond } \\
\text { donor }<5\end{array}$ & $\begin{array}{l}\text { Hydrogen bond } \\
\text { acceptor }<10\end{array}$ & Log $p$ value $<5$ & Rule of five \\
\hline 1. & Myristic acid vinyl ester & 254.41 & 0 & 2 & 4.37 & 4 \\
\hline 2. & 4-nitrophenyl laurate & 321.41 & 0 & 4 & 3.66 & 4 \\
\hline 3. & $\begin{array}{l}\text { Hexadecanoic acid, } \\
\text { 4-nitrophenyl ester }\end{array}$ & 377.52 & 0 & 4 & 4.54 & 4 \\
\hline 4. & $\begin{array}{l}\text { Dodecanoic acid, } \\
\text { 1,2,3-propanetriyl ester }\end{array}$ & 638 & 0 & 6 & 8.76 & 2 \\
\hline
\end{tabular}

compounds, the studies showed that the presence of the derivative of dodecanoic acid, viz., dodecanoic acid, methyl ester, and dodecanoic acid, 1,2,3-propanetriyl ester in acetone extract and this may be responsible for antibacterial activity. ${ }^{[10]}$ In Cnidoscolus aconitifolius, the phytocompound dodecanoic acid, 1,2,3-propanetriyl ester showed antiarthritic, nematocide, and hepatoprotective activities. ${ }^{[11]}$ The ethanol bark extract of Loranthus longiflorus infested on Casuarina equisetifolia contains mainly a fatty acid ester, viz., myristic acid and vinyl ester (82.81\%), which has antimicrobial and anti-cancer activity. ${ }^{[12]}$ Works of Sirangala show that GC-MS analysis shows the presence of myristic acid, vinyl ester, vinyl decanoate, and tridecanoic acid, which act as chemopreventive agents against prostate cancer. ${ }^{[13]}$

The methanolic extract of the Ipomoea pescaprae was identified by GC-MS analysis. Nineteen bioactive compounds were found out; among these compounds, 4-nitrophenyl laurate was found to be the highest peak area of $35.33 \%$ and possessed potential antibacterial effect. The phytochemicals have several activities, such as, antioxidant, analgesic, anti-inflammatory, antispasmodic, anti-cancer, antinociceptive, antihistaminic, insulinogenic, and hypoglycemic. ${ }^{[14]}$ Fourteen components were recorded in ethanol extract of Parthenium hysterophorus stem through GC-MS/MS and its antimicrobial activity. ${ }^{[15]}$ Among those, 4-nitrophenyl laurate showed a high peak area of 9.35\%; a similar compound was found in our experimental plant $P$. scolopendria methanolic extract.

Hexadecanoic acid, 4-nitrophenyl ester has a molecular formula of $\mathrm{C}_{22} \mathrm{H}_{35} \mathrm{O}_{4} \mathrm{~N}$; activity has not been identified. A list of acetone compounds of acetone extracts humic acids of peat, among them, hexadecanoic acid, 4-nitrophenyl ester, was also found similar to our compound. ${ }^{[16]}$ GC-MS technology was used to analyze the possible top valueadded components of benzene/ethanol extractives of Cinnamomum camphora leaves. The main constituents were hexadecanoic acid, 4-nitrophenyl ester (17.336\%). The results of function analyses showed that the $350^{\circ} \mathrm{C}$ pyrolyzate from benzene/ethanol extractives of waste leaves of $C$. camphora is abundant in materials of noble natural medicines and cosmetics. ${ }^{[17]}$

\section{Drug-likeliness Analysis using Lipinski's Rule}

The drug-likeliness analysis using Lipinski's rule of five shows that three compounds show the best result among the four compounds. The results include 1) Myristic acid vinyl ester having molecular weight 254.41, hydrogen donor- 0 , hydrogen acceptor- 2 , and the log p value of $4.37,2) 4$-nitrophenyl laurate having molecular weight 321.41 , hydrogen donor- 0 , hydrogen acceptor-4, and $\log \mathrm{p}$ value of $3.66,3$ ) Hexadecanoic acid, 4-nitrophenyl ester having molecular weight 377.52 , hydrogen donor- 0 , hydrogen acceptor-4, and the log p value of 4.54 (Table 2). Since these compounds satisfy Lipinski's rules of five, they were further selected for docking analysis.

\section{Docking Analysis}

The goal of ligand-protein docking is to predict the predominant binding model(s) of a ligand with a protein of known three-dimensional structure. Docking studies yield crucial information concerning the orientation of the inhibitors in the binding pocket of the target protein. Several potential inhibitors have been identified through the docking simulation. The majority of the ligands had a greater binding affinity with the target cancer proteins. Inhibition was measured by the binding affinity of the best ligand pose measured in $\mathrm{kcal} / \mathrm{mol}$. 
Four GC-MS chemical compounds from P. scolopendria (Burm. f.) Pic. Serm. were subjected to docking. Docking of modified structures is done with the Discovery Studio 2.1 version software tool considering target protein as a receptor to identify their energy values. Docking helps us to virtually screen the number of compounds and predict the strongest binders based on scoring functions. It calculates how the receptor and ligand fit together and dock to each other well.

It has been observed that three ligands docked successfully responded by docking tool. In this study, compounds, like myristic acid vinyl ester, 4-nitrophenyl laurates have antimicrobial and anti-cancer activities. These compounds are docked with 2ITO protein (Table 3 ). The binding nodes of myristic acid vinyl ester (ligand) docked with lung cancer protein (2ITO) show that the ligand has interacted with one basic polar amino acid LYS 745. Green lines showing hydrogen bond interacting with 2ITO protein with the bond length of $2.3487 \AA$ with the LibDock score of 90.118 (Fig. 2).

Likewise, the binding nodes of 4-nitrophenyl laurate docked with lung cancer protein 2ITO show that the ligand has interacted with one basic polar amino acid Lys 728 . Interacting with two hydrogen bonds with the bond length of 2.38011 and 2.14353 $\AA$, respectively, as green line shows the interaction with the LibDock score of 121.43 (Fig. 3).

Hexadecanoic acid, 4-nitropheyl ester docked with 2ITO protein, shows that the ligand has interacted with two amino acids (threonine and lysine). Polar amino acid Theronine Thr 790 interacted with two hydrogen bonds with a bond length of 2.48432 and 2.26158 A. Basic polar amino acid Lysine Lys 745 interacted with one hydrogen bond with a bond length of 2.07509 with the LibDock score of 114.54 (Fig. 4).

The report showed that plants having phenolic compounds, such as, coumar, have bronchodilator activity ${ }^{[3]}$ Hence, the compounds were docking against lung cancer protein to know the interaction and druglikeliness properties.

\section{Pharmacokinetic Analysis}

Table 4 illustrates the pharmacokinetic properties of the bioactive compounds. According to the results, the oral bioavailability was high for two compounds, viz., myristic acid vinyl ester and 4-nitrophenyl laurates, and low for the other two compounds, viz., hexadecanoic acid, 4-nitrophenyl ester and dodecanoic acid, 1,2,3-propanetriyl ester. The compound myristic acid vinyl ester alone cross the blood-brain barrier; penetration through the skin was better for three compounds.

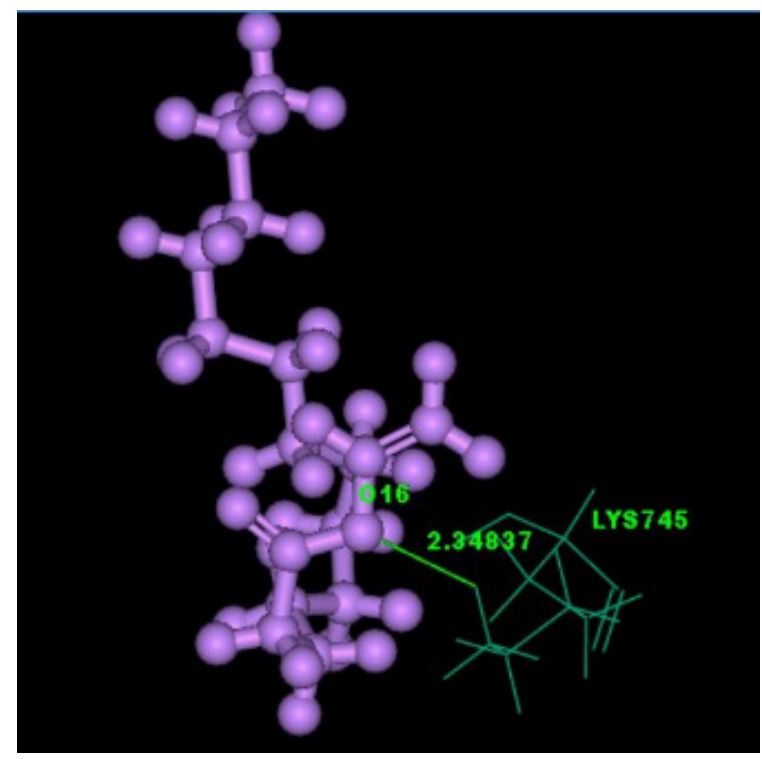

Fig. 2: Docking of myristic acid vinyl ester with 2ITO interactions between myristic acid and receptor (2ITO) with hydrogen bond(s) (indicated as a green line)

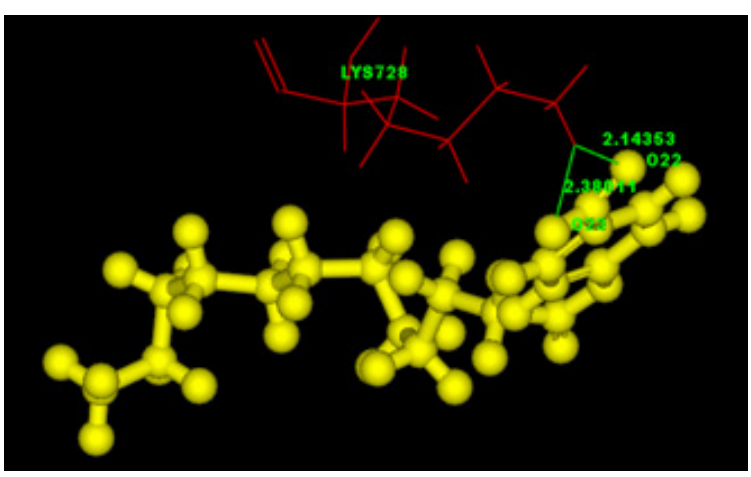

Fig. 3: Docking of 4-nitrophenyl laurate with 2ITO interactions between 4-nitrophenyl laurate and receptor (2ITO) with hydrogen bond(s) (indicated as a green line)

Table 3: Docking result of lung cancer protein with various compounds obtained from P. scolopendria (Burm. f.) Pic. Serm.

\begin{tabular}{|c|c|c|c|c|c|c|c|c|}
\hline Compounds & $P D B-I D$ & $\begin{array}{l}\text { No. of } \\
\text { posses }\end{array}$ & $\begin{array}{l}\text { Absolute } \\
\text { energy }\end{array}$ & LibDock scores & $\begin{array}{l}\text { No. of } H \\
\text { bonds }\end{array}$ & $\begin{array}{l}\text { Bond } \\
\text { length }(\AA)\end{array}$ & $\begin{array}{l}\text { Interacting } \\
\text { amino acids }\end{array}$ & $\begin{array}{l}\text { Interacting } \\
\text { atoms }\end{array}$ \\
\hline $\begin{array}{l}\text { Dodecanoic acid, } \\
\text { 1,2,3-propanetriyl ester }\end{array}$ & 2ITO & 0 & - & - & - & - & - & - \\
\hline Myristic acid vinyl ester & 2ITO & 100 & 21.481 & 90.118 & 1 & 2.34837 & LYS745 & 016 \\
\hline 4-nitrophenyl laurate & 2ITO & 98 & 33.213 & 121.432 & 2 & $\begin{array}{l}2.14353 \\
2.38011\end{array}$ & LYS728 & $\begin{array}{l}023 \\
022\end{array}$ \\
\hline $\begin{array}{l}\text { Hexadecanoic acid, } \\
\text { 4-nitrophenyl ester }\end{array}$ & 2ITO & 99 & 35.638 & 114.54 & 3 & $\begin{array}{l}2.07509 \\
2.48432 \\
2.26158\end{array}$ & $\begin{array}{l}\text { LYS745 } \\
\text { THR790 }\end{array}$ & $\begin{array}{l}017 \\
026\end{array}$ \\
\hline
\end{tabular}


Table 4: Pharmacokinetics properties of bioactive compounds of P. scolopendria (Burm. f.) Pic. Serm.

\begin{tabular}{|c|c|c|c|c|c|c|c|c|c|}
\hline Name of ligand & $\begin{array}{l}\text { GI } \\
\text { absorption }\end{array}$ & $\begin{array}{l}\text { BBB } \\
\text { permeability }\end{array}$ & $\begin{array}{l}\text { P-gp } \\
\text { substrate }\end{array}$ & $\begin{array}{l}\text { CYP1A2 } \\
\text { inhibitor }\end{array}$ & $\begin{array}{l}\text { CYP2C19 } \\
\text { inhibitor }\end{array}$ & $\begin{array}{l}\text { CYP2C9 } \\
\text { inhibitor }\end{array}$ & $\begin{array}{l}\text { CYP2D6 } \\
\text { inhibitor }\end{array}$ & $\begin{array}{l}\text { CYP3A4 } \\
\text { inhibitor }\end{array}$ & $\begin{array}{l}\log K_{p} \text { (skin } \\
\text { permeation) } \\
(\mathrm{cm} / \mathrm{s})\end{array}$ \\
\hline $\begin{array}{l}\text { Dodecanoic acid, } \\
\text { 1,2,3-propanetriyl ester }\end{array}$ & Low & No & Yes & No & No & No & No & No & 0.76 \\
\hline Myristic acid vinyl ester & High & Yes & No & Yes & No & Yes & No & No & -2.95 \\
\hline 4-nitrophenyl laurate & High & No & No & Yes & No & No & No & No & -3.53 \\
\hline $\begin{array}{l}\text { Hexadecanoic acid, } \\
\text { 4-nitrophenyl ester }\end{array}$ & Low & No & Yes & No & No & No & No & Yes & -2.33 \\
\hline
\end{tabular}

GI absorption: Gastrointestinal absorption; BBB: Blood-brain barrier; CYP: Cytochrome P

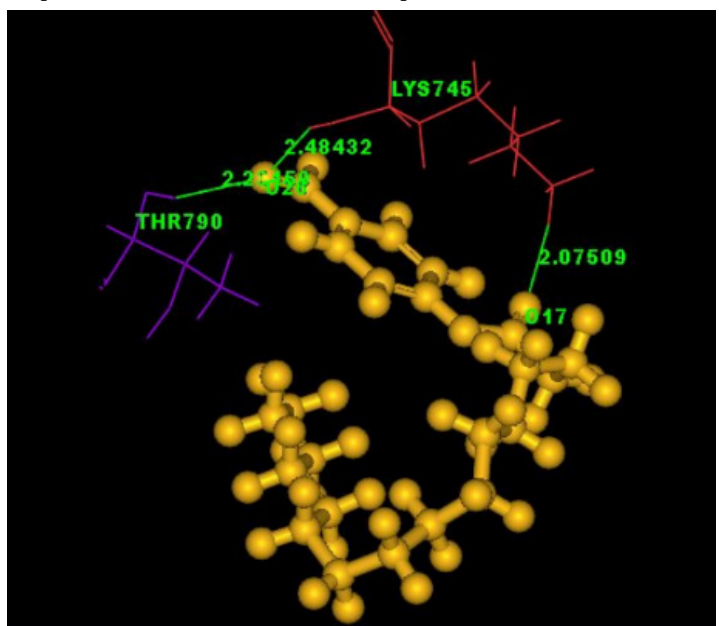

Fig. 4: Docking of hexadecanoic acid, 4-nitrophenyl ester with 2ITO interactions between hexadecanoic acid, 4-nitrophenyl ester, and receptor (2ITO) with hydrogen bond(s) (indicated as a green line)

\section{CONCLUSION}

The present study showed that plant derivative obtained from the GC-MS analysis of $P$. scolopendria (Burm. f.) Pic. Serm. could be a potent inhibitor against lung cancer protein on the basis of docking scores. We anticipate that further exploration of the compound's functions and molecular mechanisms will facilitate a better understanding for the control of lung cancer and the development of anti-cancer drugs. This dry lab study helps us move on for wet lab or in vitro procedure to confirm the same and find out the exact compound responsible for its bioactivity. However, based on the results of these in silico studies, further studies are desirable to prove the anti-cancer property, especially lung cancer.

\section{ACKNOWLEDGEMENT}

The authors express their acknowledgments to the management, Principal Dr. (Sr.) A. Christina Bridget and Head of Department Dr. P. Shanthi, for the support successfully rendered during this work. We express our gratitude to Dr. M. Rajalakshmi, Department of Biotechnology and Bioinformatics, for carrying out docking work and VIT, Vellore, for GC-MS analysis.

\section{REFERENCES}

1. WHO: World Health Organization. Medicinal plants in the South Pacific. Manila: WHO regional publications. 1998.141

2. Beaujard P. Plants and traditional medicine in south-eastern Madagascar. Journal of Ethanopharmacology. 1988;23:165-185.

3. Ramanitrahasimbola D, Rakotondramanana DA, Rasoanaivo P, Randriantsoa A, Ratsimamanga S, Palazzino G, et al. Bronchodilator activity of Phymatodes scolopendria (Burm.) Ching and its bioactive constituent. Journal of Ethnopharmacology. 2005;102(3):400-407.

4. Petard P, Florence J. Some useful plants from French Polynesia and Raau Tahiti. Editions Haere Po No Tahiti. 1986.

5. Whistler WA. Polynesian herbal medicine. National Tropical Botanical Garden; 1992.

6. Mannan MM, Maridass M, Victor B. A review on the potential uses of ferns. Ethnobotanical Leaflets. 2008;(1):33.

7. Sujatha S, Ramya RI, Gayathri M, Catharin SS. Preliminary phytochemical screening and spectroscopic analysis of Phymatosorus scolopendria (Burm. f.) Pic. Serm. Int. Res. J. Pharm. 2018;9(7):168-172.

8. Descheemaeker, A. Ravimaitso, 2nd ed. Fianarantsoa: Saint Paul Printing;1979. p. 76.

9. Lipinski CA, Lombardo F, Dominy BW, Feeney PJ. Experimental and computational approaches to estimate solubility and permeability in drug discovery and development settings. Advanced Drug Delivery Reviews. 1997 Jan 15;23(1-3):3-25.

10. Sharma DU, Rani RE, Chaturvedi MO, Yadav JP. Antibacterial efficacy and gas chromatography-mass spectrometry analysis of bioactive compounds present in different extracts of Allium sativum. Asian Journal Pharm Clin Res. 2018;11:280-286.

11. Achi NK, Ohaeri OC. GC-MS determination of bioactive constituents of the methanolic fractions of Cnidoscolus aconitifolius. Journal of Pharmaceutical Research International. 2015:163-172.

12. Chandrakasan L, Neelamegam R. GC-MS analysis of Loranthus, longiflorus Desr.(a Hemi-parasite) bark harvested from two host trees. Journal of Pharmacy Research. 2011;4(9):3072-3074.

13. Sirangala TG, Antiproliferative Effect of Rhus Succedanea, Rheum Emodi, and Gardenia Gummifera in Prostate PC-3 Cells. International Journal of Pharmacy and Biological Sciences. 2019;9(1):705-710.

14. Kumar A, Paul S, Kumari P, Somasundaram ST, Kathiresan K. Antibacterial and phytochemical assessment on various extracts of Ipomoea Pes-caprae (L.) R. Br through FTIR and GC-MS spectroscopic analysis. Asian J Pharm Clin Res. 2014;7(3):134-138.

15. Krishnaveni M, Kalaivani M, Banu CR, Kumari GK. GC-MS/MS Study of Parthenium hysterophorus L (N. Am) stem, antimicrobial activity. Research Journal of Pharmacy and Technology. 2015;8(5):517-519.

16. Platonov V, Belozerova LI, Gorokhova MN. Comparative characteristics of the chemical composition and biological activity of extracts of humic acids of peat (Jaroslavskiy region, Breitovskiy region). Journal of New Medical Technologies. 2018;8-24.

17. Liu QM, Zhang DQ, Peng WX, Peng K. Identification of chemical components of waste leaves from Cinnamomum camphora by Py-GC/ MS. InAdvanced Materials Research. 2011;230:842-846. 